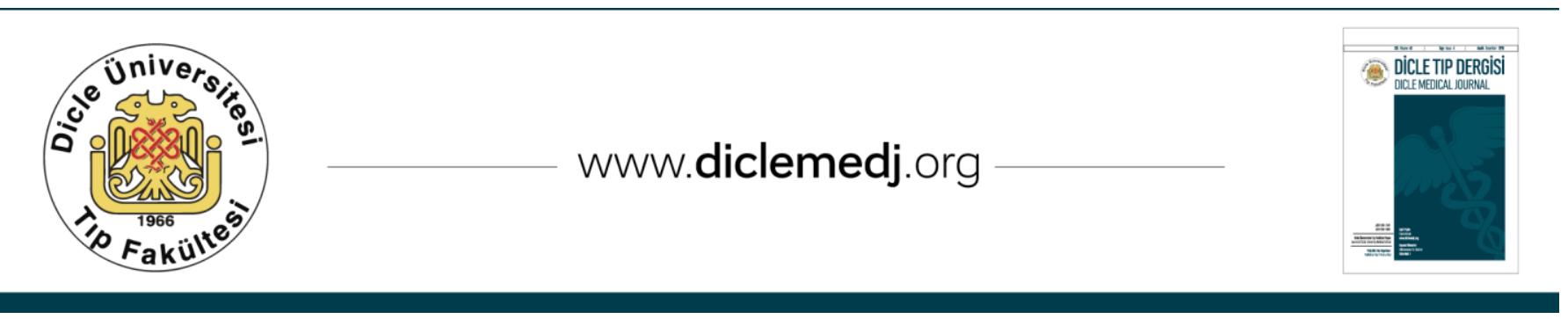

Olgu Sunumu / Case Report

\title{
Ailesel Akdeniz Ateşi Atağına Eşlik Eden Erizipel Benzeri Eritem
}

\author{
Emine Müge Acar1, Senem Şaş² \\ 1 Ahi Evran Üniversitesi Eğitim Ve Araștırma Hastanesi, Dermatoloji, Kırşehir, Türkiye \\ 2 Ahi Evran Üniversitesi Eğitim Ve Araştırma Hastanesi, Fiziksel Tıp Ve Rehabilitasyon, Kırşehir, Türkiye
}

Geliş: 13.10.2016; Revizyon: 31.01.2017; Kabul Tarihi: 07.02.2017

\section{Özet}

Ailevi Akdeniz Ateşi (AAA) tekrarlayan ateş ve poliserozitle karakterize, en sık görülen ailesel, monogenik geçişli otoinflamatuar bir hastalıktır. Erizipel benzeri eritem AAA'nın tipik ancak nadir görülen bir deri bulgusudur. Alt ekstremitelerde, dizin alt kısmı, ayak sırtında ve ayak bileğinde yerleşim gösteren sıcak ve hassas eritematöz plaklarla karakterizedir. Özellikle AAA'nın başlangıç bulgusu olarak ortaya çıktığında erizipel olarak değerlendirilerek yanlıș tanı konabilmektedir. Burada, AAA tanısı ile takipte olan ve kolşisin tedavisine uyum göstermeyen ve sonrasında AAA atağıyla birlikte erizipel benzeri eritemle başvuran 24 yaşında bir erkek hasta sunulmaktadır.

Anahtar kelimeler: Ailesel Akdeniz Ateşi, erizipel, eritem

\section{Erysipelas Like Erythema Accompanying Familial Mediterranean Fever Attack}

\begin{abstract}
Familial Mediterranean Fever (FMF) is the most common familial monogenic autoinflamatory disease characaterized by recurrent fever and polyserositis. Erysipelas like erythema is a typical but rare cutaneous finding in FMF and characterized by tender erythematous plaques located on lower limbs, leg, dorsum of the foot and ankle. The lesions can be misdiagnosed as eryspileas especially when seen as a initial symptom of FMF. We present here an example of erysipelas like erythema accompanying FMF attack as a result of non-adherence to oral colchicine treatment.
\end{abstract}

Keywords: Familial Mediterranean Fever, Erysipelas, erythema

DOI: $10.5798 /$ dicletip. 298593

Yazışma Adresi / Correspondence: Senem Şaş, Kervansaray Mah. 2019 sok. No:1 Kırşehir, Türkiye Email: senemsas@gmail.com 


\section{GİRIŞ}

Ailesel Akdeniz Ateşi (AAA) otozomal resesif olarak geçen, tekrarlayan ateș, peritonit, plörit ve serözit ve artritle karakterize kalıtsal bir hastalıktır. Sefardik Yahudileri, Araplar, Ermeniler ve Türkler gibi belli etnik gruplarda sık olarak görülmektedir [1]. AAA' nın en ciddi komplikasyonu, son dönem böbrek yetmezliğine neden olabilen amiloidozdur [1,2]. $\mathrm{Bu}$ nedenle hastalığa erken tanı konulması önemlidir. AAA'da Henoch Schlonlein purpurası, nonspesifik purpura, yüz, gövde ve avuç içlerinde eritem, anjionörotik ödem, Reynaud fenomeni, piyoderma ve subkutanöz nodüller gibi pek çok deri bulgusu görülmekle birlikte sadece erizipel benzeri eritem (EBE) AAA için patognomonik bir bulgudur [3]. EBE tipik olarak ayak dorsumunda, ayak bileğinde bacakların ekstansör yüzlerinde yerleşim gösterir [1]. EBE iyi sinırl, $15-50 \mathrm{~cm}$ arası boyutta ve tipik olarak tek taraflıdır [4]. Burada, AAA tanısı ile takipte olan ve ilaç tedavisine uyum göstermeyen ve sonrasinda AAA atağıyla birlikte EBE ile başvuran 24 yaşında bir erkek hasta sunulmaktadır.

\section{OLGU SUNUMU}

24 yaşında erkek hasta sağ ayak bileğinde kızarıklık ve hassasiyet şikayetiyle hastanemize başvurdu. Hastanın eklem ağrısı ve karın ağrısı şikayeti mevcuttu. Hastanın hikayesinden 14 yıldan beri AAA tanısıyla takipli olduğu ve daha önce yapılan gen analizinde M694V gen mutasyonu homozigot olarak pozitif saptandiğ öğrenildi. Hasta 14 yıldan beri kolşisin kullanmaktaydı. Ancak, son üç aydır ilacını almadığı bilgisine ulaşıldı. Hastanın dermatolojik muayenesinde sağ ayak bileği medial malleolun yukarısından başlayıp aşağıya uzanım gösteren yaklaşık $10 \mathrm{~cm}$ uzunluğunda, eritemli, basmakla hassasiyetin mevcut olduğu endure plak saptandı (Resim 1). Hastanın sağ ayak bileği ve sağ dizinde aktif artrit bulguları mevcuttu. Laboratuar tetkiklerinde tam kan sayımı normal, biyokimya normal, CRP değeri 1,25 (0,015-0,5) olarak geldi. Tam idrar tetkikinde $2+$ proteinüri saptandı. Hastaya bu bulgularla AAA atağ 1 tanısı kondu. Hastanın AAA tanısının olması, tedaviye ara vermiş olması nedeniyle ön tanıda erizipel benzeri eritem düşünülerek hastaya istirahat önerildi. Ayırıcı tanı için yumuşak doku ultrasonu yapıldı, enfeksiyon bulgusuna rastlanmadığı rapor edildi. Kolşisin $1.5 \mathrm{mg}$ /gün tedavisine yeniden başlanarak sülfosalazin 1000 mg/gün eklendi. Hastanın takibinde lezyonların 3. günde gerilediği gözlendi. Hastanın üç ay sonraki kontrolünde deri lezyonlarında nüks izlenmedi.

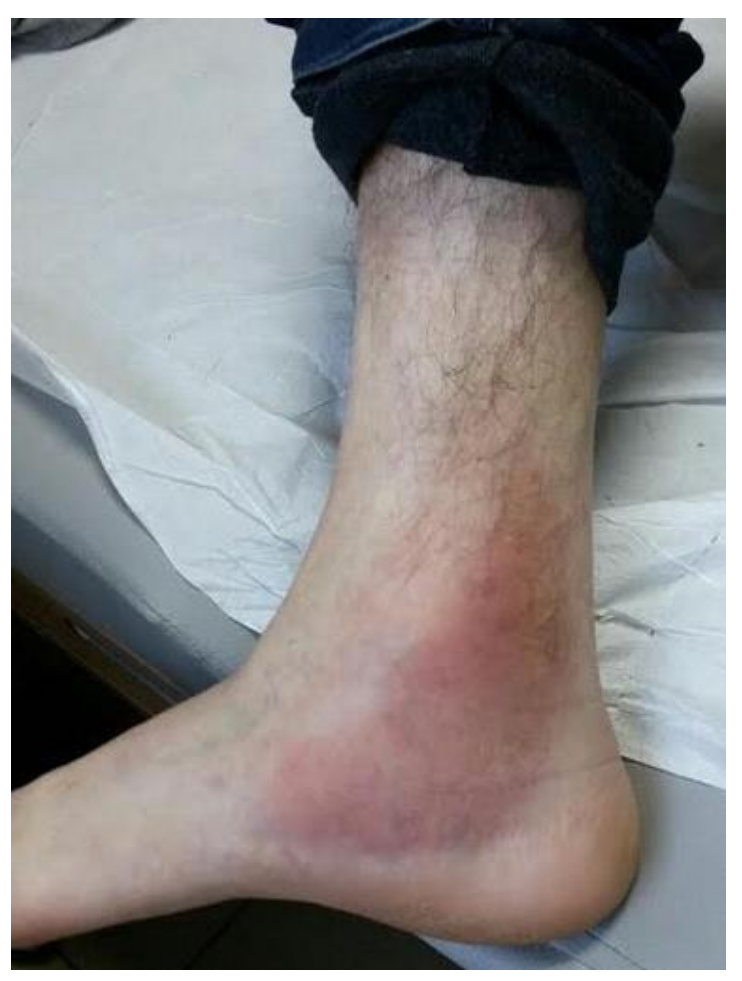

Resim 1: Sağ ayak medialinde keskin sınırlı eritemli plak

\section{TARTIŞMA}

AAA, dünyada en sık görülen monogenik otoinflamatuar hastalıktır [4] AAA hastalarında on altıncı kromozomda lokalize pirin proteinini kodlayan MEFV geninde mutasyon saptanmıștır. Ülkemizde en sık görülen 
mutasyonlar M694V, V726A, M680I, M694I ve E148Q mutasyonlarıdır [1]. Ceşitli çalışmalarda M694V mutasyonu erken başlangıç ve şiddetli hastalıkla ilişkili bulunmuștur [2,5].

Hastalığın kliniğinde \%95 oranında karın ağrısı görülür. Karın ağrısı 2-3 gün içinde geriler [1]. Plörite bağlı göğüs ağrısı hastaların \%2362'sinde, artrit \%37-77'sinde görülür. Artrit ani başlangıçlı, monoartiküler, genellikle diz, ayak bileği ve kalça eklemlerini sık olarak tutar. Eklem eritemli, sıcak, hassas, ödemlidir ve septik artritle karıștırılabilir. Artrit genellikle egzersiz veya travmaya sekonder gelișir, sekelsiz bir haftada iyileşir [4].

AAA hastalarının \%7-40'ünde erizipel benzeri eritem görülmektedir [1,4]. EBE 18 yaşından önce tanı alan AAA olgularında daha sık rastlanmaktadır [5]. Olgumuzun 10 yaşından önce tanı almış olması literatür bilgilerini desteklemektedir.

Hastaların AAA tanısı alırken ilk başvuru şikayeti olabilmektedir. EBE alt ekstremiteler, ayak bileği ve ayak dorsaline yerleşir. Plaklar eritemli, sıcak ve hassastır. [4]. Lezyonlar fiziksel aktivite ile tetiklenebilmekte ve istirahatle, spontan olarak 48-72 saat içinde gerileyebilmektedir. Barzilai ve ark. EBE'nin kompleman aktivasyonu ve nötrofil migrasyonu ile karakterize kontrolsüz inflamatuar yanıttan kaynaklandığını öne sürmüşlerdir [3]. Hastanın AAA tanısı olması ve daha önceki ataklarında benzer lezyonların geliştiğini tariflemesinden dolayı EBE tanısı konuldu. Burada sunulan olguda erizipel benzeri eritem AAA alevlenmesine eşlik eden bir semptom olarak göze çarpmaktadır

Özlü ve ark.'nın yaptığı bir çalışmada AAA'da erizipel benzeri eritemin \%15 oranında görüldüğü ve M694V homozigot olan grupta EBE’nin, bu mutasyonu taşımayan gruba göre daha sık olarak görüldüğü bildirilmiştir [2].Olgumuzda da benzer olarak M694V homozigot pozitifliği bulunmaktaydı.
Ayrıca artrit varlığında EBE sıklığında artış bildirilmiştir [5]. Olgumuzda benzer olarak artrit de tespit edilmiştir.

Bayram ve ark. AAA'da erizipel benzeri eritem ve miyaljinin sublinik inflamasyonda bağımsız risk faktörleri olduğunu ve hastaların ataksız dönemde de subklinik inflamasyon açısından takip edilmesi gerektiğini vurgulamıştır [6].

Erizipel benzeri eritemin histopatolojik incelemesinde perivasküler alanda papiller yerleşimli diffüz, eozinofil, nötrofil ve monositlerden oluşan inflamatuvar hücre infiltrasyonu görülür. Retiküler dermiste az sayıda lenfosit infiltrasyonu ve belirgin ödem vardır [4]. Olgumuz biyopsi alınmasını kabul etmemekle birlikte M694V gen pozitifliği bulunması, daha önce AAA tanısının bulunması ve lezyonların 2-3 gün içinde gerilemesiyle klinik olarak erizipel benzeri eritem tanısı konmuştur.

Erizipel benzeri eritemin ayırıcı tanısında sellülit, erizipel, eritema nodozum, eritema induratum, staz dermatiti de akılda bulundurulmalıdır [7,8]. EBE paraneoplastik bir bulgu olarak da gelişebilmektedir. Huang ve ark.'ın yayınladığı vaka raporunda renal hücreli kanserde paraneoplastik olarak gelişen erizipel benzeri eritemin tümör eksizyonu sonrası gerilediği bildirilmiştir [9].

\section{SONUÇ}

Burada sunulan olguda, AAA tedavisine ara verme sonucunda EBE ortaya çıkmıştır. Bacakta kızarıklık şikayeti olan hastalarda EBE'nin de ayırıcı tanıda bulundurulması önemlidir. Enfeksiyon dışında erizipel benzeri eritem varlığında AAA akla getirilmelidir. Ayırıcı tanı uygun tedavi prosedürlerinin uygulanması için gereklidir.

\section{Teşekkür}

$\mathrm{Bu}$ yazıda verdiği destekten ötürü Yard. Doç. Dr. Hatice Sinem Şaş’a teşekkür ederiz. 
Çıkar Çatışması Beyanı: Yazarlar çıkar çatışması olmadığını bildirmişlerdir.

Finansal Destek: Bu çalışma her hangi bir fon tarafından desteklenmemiştir.

Declaration of Conflicting Interests: The authors declare that they have no conflict of interest.

Financial Disclosure: No financial support was received.

\section{KAYNAKLAR}

1. Kucuk A, Gezer IA, Ucar R, et al. Familial Mediterranean Fever. Acta Medica (Hradec Kralove). 2014; 57:97-104.

2. Özlü SG, Ergüven M, Hamzah ÖY. Genotype and Phenotype correlations in children with Familial Mediterranean Fever. Turkish J Pediatr Dis. 2015; 3:171-5.

3. Barzilai A, Langevitz P, Goldberg I, et al. Erysipelas like erythema of familial Mediterranean fever: clinicopathologic correlation. J Am Acad Dermatol. 2000; 42:791-5.
4. Dilek N, Ukşal Ü. Çocuklarda otoinflamatuar hastalıkların deri bulguları. Turk J Dermatol 2014; 8:216-22.

5. Tunca M, Akar S, Onen F, et al. Turkish FMF study group; Familial Mediterranean fever (FMF) in Turkey: results of a nationwide multicenter study. Medicine (Baltimore). 2005; 84:1-11.

6. Bayram MT, Çankaya T, Bora E, et al. Risk factors for subclinical inflammation in children with familial Mediterranean fever. Rheumatol Int. 2015; 35:1393-8.

7. Halpern AV, Heymann WR. Bacterial Diseases. In: Bolognia JL, Jorizzo JL, Rapini RP,eds. Dermatology, 2nd edn. Spain: Mosby, 2008: 1082-3.

8. Strazzula L, Cotliar J, Fox LP, et al. Inpatient dermatology consultation aids diagnosis of cellulitis among hospitalized patients: a multi-institutional analysis. J Am Acad Dermatol. 2015; 73:70-5.

9. Huang H, Du J, Hwang SK, et al. Pretibial erysipelas-like erythema as the primary manifestation of renal cell carcinoma, a paraneoplastic manifestation. Eur J Dermatol. 2014; 24:130-1. 